\title{
Influência de Polimorfismos e Metilação na Expressão de MDR1 e do Choque Térmico em Genes de Resistência a Múltiplas Drogas*
}

\author{
The Influence of Polymorphisms and Methylation on MDRI Expression and the \\ Heat Shock on Multi-drug Resistance Genes
}

\author{
Juliano Javert Lourenço', Miguel Ângelo Martins Moreira²
}

\section{Resumo}

A proteína P-gp1 é codificada pelo gene $M D R 1$ humano e está envolvida com o desenvolvimento de resistência a quimioterápicos, não relacionados entre si, em tumores, o que caracteriza a "resistência a múltiplas drogas" (MDR). A expressão aumentada de P-gp1 é atribuída a mecanismos moleculares que podem alterar a regulação transcricional desse gene. Entre os mecanismos, está a alteração do status metilacional nos sítios CpG e polimorfismos genéticos no promotor de $M D R 1$, além das respostas ao estresse causado, entre outros fatores, por exposição ao calor. A expressão e atividade elevada de P-gp1 na Leucemia Mielóide Aguda (LMA) pode ser utilizada como fator prognóstico. Um total de $20 \%$ dos pacientes com LMA de novo e $75 \%$ dos casos de LMA secundária expressam P-gp1. Embora $60 \%$ a 70\% dos pacientes com LMA de novo apresentem remissão completa frente à quimioterapia, apenas $25 \%$ a mantém, os remanescentes recaem e/ou morrem devido à MDR. Neste trabalho, foram analisadas a associação entre polimorfismos na região promotora de $M D R 1$ em células leucêmicas de 72 pacientes com LMA e a atividade e expressão de P-gp1. Também foi analisada a associação entre a densidade metilacional e a atividade e expressão de P-gp1 em um trecho funcional da região promotora de $M D R 1$ em células leucêmicas de 14 pacientes e em duas linhagens celulares com (Lucena) e sem (K562) o fenótipo MDR. Também foi comparada a expressão gênica dos genes de resistência $M D R 1, M R P 1, B C R P$ e do fator de transcrição $H S F 1$, nas linhagens celulares leucêmicas, K562 e Lucena, tratadas e não tratadas com 5-Azacitidina, antes e após a exposição a choque térmico $\left(2\right.$ horas a $43^{\circ} \mathrm{C}$ ). A análise de $665 \mathrm{pb}$ da região promotora do gene MDR1 revelou um SNP denominado $-129 \mathrm{~T} /$ C e uma substituição não descrita na posição 68 do íntron 1. A frequência dos genótipos do SNP $-129 \mathrm{~T} / \mathrm{C}$ foram: $83,3 \%$ TT (60/72), 15,7\% T/C, (11/72) e 1,3\% C/C (1/72). O ensaio com Rodamina-123 executado em 64 pacientes mostrou um fenótipo MDR em $52 \%$ dos pacientes analisados. A expressão de P-gp1 foi analisada em $58 \%$ dos pacientes com LMA e a superexpressão de P-gp1 foi encontrada em $81 \%$ do total de pacientes analisados. Nenhuma associação estatística significante foi encontrada entre qualquer um dos genótipos, -129T/T ou -129T/ C, e a atividade ou expressão de P-gp1. O padrão de metilação foi analisado em 14 pacientes para uma região de 223pb do promotor, abrangendo 12 sítios CpG. Os sítios CpG localizados em -141, -131 e -102 bases do sítio de início de transcrição estavam não metilados em aproximadamente $70 \%$ dos pacientes. Os sítios localizados em 48, -31 e -26 mostraram-se metilados em 10\% dos pacientes. Além disso, um paciente mostrou todos os sítios CpG em estado metilado/não metilado e três pacientes mostraram todos os sítios não metilados. A linhagem Lucena apresentou baixo estado metilacional para a maioria de seus sítios CpG, enquanto em K562 apenas 33\% dos sítios CpG apresentaram-se metilados. Não foi encontrada qualquer associação entre a expressão e atividade

\footnotetext{
${ }^{1}$ Autor

${ }^{2}$ Orientador, Pesquisador do Laboratório de Genética /Coordenação de Pesquisa (CPQ) / Instituto Nacional de Câncer (INCA)

*Tese apresentada no Programa de Pós-Graduação em Ciências Biológicas do Instituto de Biologia da Faculdade Federal do Rio de Janeiro (UFRJ)

Endereço para correspondência: miguelm@inca.gov.br; julianojavert@hotmail.com
} 
de P-gp1 e a metilação em pacientes. Os experimentos de choque térmico mostraram que houve um discreto aumento do nível de expressão do gene MDR1 nas células submetidas apenas ao choque térmico em relação aos seus controles, tanto em K562 quanto Lucena. Também mostraram que há aumentos modestos na quantificação relativa do ARN mensageiro de $M D R 1, M R P 1$ e $H S F 1$ quando as linhagens são submetidas ao choque térmico após o tratamento com o agente 5-Azacitidina. Neste último caso, para $M R P 1$, houve aumento transcricional mais evidente em K562 em relação aos outros genes MDR. A presença de motivos de reconhecimento para o fator de transcrição HSF1 no próprio promotor de HSF1 sugerem a possibilidade de um feedback positivo relacionado à ativação de sua própria transcrição. Não foi detectada a expressão de $B C R P$ nas linhagens K562 e Lucena, mesmo após o tratamento com 5-Azacitidina. 